\title{
THE GENETICS OF INFLAMMATORY BOWEL DISEASE
}

\author{
Dr R B McCONNELL, TD, MD, FRCP
}

Broadgreen Hospital, Liverpool

It is of interest that when Crohn described regional enteritis his first patient had a sister who also was found to have the same condition $\left(\mathrm{Crohn}^{1}\right)$. In fact, Crohn in his original article called it Familial Ileitis. When he realised it often was not familial he changed the title to Terminal Ileitis, and then when the patients thought they had some dreadful terminal disease it was changed to Regional Ileitis.

\section{Family aggregations}

Interest in the question of the genetics of the two components of Inflammatory Bowel Disease was aroused in the early 60's when a pedigree was published (Almy and Sherlock ${ }^{2}$. Up to then people had reported Crohn's disease and Ulcerative Colitis in the same family, but the diagnoses were always rather suspect. There is no doubt that in this report we were dealing with cases of Crohn's disease and cases of Ulcerative Colitis in the same family. There was also a colitic member of the family who had ankylosing spondylitis of which I will be speaking later.

What are the reasons for such a family aggregation of Crohn's disease and Ulcerative Colitis? I think there are four. It could be chance. These are not rare diseases and if you take the 200 million population of the United States, by chance alone one should be able to get some families with two, three, four or maybe even five or six cases of these diseases just occurring by chance even if there was no relationship between them. Another possible cause is that there is some strong genetic factor which causes these diseases to occur particularly in centain families and not in others. A third possible cause is that the common environment of a family would cause these diseases to occur. For example, if sago was the cause of Crohn's disease and some families ate sago and others didn't then you would expect it to occur in some families and not others. The fourth possibility is a combination of genetic and environmental factors so that there is a strong environmental factor operating widely or locally but causing the diseases in individuals with an inherited predisposition.

This was an isolated family. Table $I$ is a compilation of the reports of familial cases of Inflammatory Bowel Disease up to 1977. The Ulcerative Colitis data is in the first column, Crohn's disease in the second and then there is a column in which there have been reports of both Crohn's disease and Ulcerative Colitis in the same family. These data of course only illustrate the distribution of familial cases. They are quits unreliable for any form of analysis because what provokes somebody to report a case in the literature and not another case is all imporant Parent-child and sib-sib combinations have been reported much more commonly than more distant rclatives. You will note that there have been three instances of 
Table I

Reports of familial occurrence of inflammatory bowel disease

\begin{tabular}{|c|c|c|c|}
\hline & $\begin{array}{l}\text { Ulcerative } \\
\text { colitis }\end{array}$ & $\begin{array}{l}\text { Crohn's } \\
\text { disease }\end{array}$ & $\begin{array}{l}\text { Both } \\
\text { types }\end{array}$ \\
\hline Parent - child & 43 & 18 & 7 \\
\hline Siblings & 51 & 27 & 12 \\
\hline $\begin{array}{r}\text { Monozygous twins: Concordant } \\
\text { Discordant }\end{array}$ & $\begin{array}{l}5 \\
6\end{array}$ & 7 & $\begin{array}{l}0 \\
0\end{array}$ \\
\hline Dizygous twins & 1 & 2 & 0 \\
\hline Collateral relatives & 13 & 14 & 9 \\
\hline Husband and wife & 1 & 1 & 1 \\
\hline
\end{tabular}

husband and wife affection. In one instance they both had Ulcerative Colitis, in another they had Crohn's and in a third, one had Crohn's and the other Ulcerative Colitis. It is interesting that among the reported twins, there has never been a mixture.

\section{Positive family history}

The number of people with a positive family history in reported series of Crohn's disease patients has been very variable but on the whole it has been uncommon in a group of patients with Crohn's disease to find one who has an affected relative. These reports probably underestimate because they are merely what the patients know of their relatives and people can be quite ignorant of the state of health of even their own brothers and sisters in other towns.

Kirsner's data in Table II are really much more valuable (Kirsner and Spen-

Table II

Inflammatory bowel disease - affected relatives

(From Kirsner and Spencer 1963)

\begin{tabular}{|l|c|c|c|c|c|}
\hline Disease & $\begin{array}{c}\text { Number } \\
\text { of } \\
\text { patients }\end{array}$ & $\begin{array}{c}\text { Number } \\
\text { with } \\
\text { positive } \\
\text { family } \\
\text { history }\end{array}$ & $\begin{array}{c}\text { Ulcerative } \\
\text { colitis }\end{array}$ & $\begin{array}{c}\text { Regional } \\
\text { enteritis }\end{array}$ & Ileocolitis \\
\hline Ulcerative colitis & 1084 & 66 & 75 & 13 & 1 \\
\hline Regional enteritis & 185 & 20 & 9 & 12 & 1 \\
\hline Ileocolitis & 70 & 5 & 4 & 1 & 0 \\
\hline
\end{tabular}

cer $\left.^{3}\right)$. They show the family history of the patients attending his clinic in Chicago and there are several features which are of interest. One is that out of 1084 cases of Ulcerative Colitis there were only 66 with a positive family history whilst with Crohn's disease, 20 out of 185 had a positive family history. In other words, it would appear that Crohn's disease is much more often familial than Ulcerative Colitis and this is also our finding in Liverpool. The other thing to notice in the data is that amongst the relatives of those with both diseases there are plenty with the opposite disease With the Ulcerative Colitis patients there are 13 with relatives 
affected by Crohn's and amongst the Crohn's disease there are nine who had relatives with Ulcerative Colitis. Later, Kirsner ${ }^{4}$ reported that 31 of 103 positive families included both types of Inflammatory Bowel Disease. I used to regard these data with a certain scepticism in that I thought that the differential diagnosis of Crohn's and Ulcerative Oolitis is so difficult that it was hard to be certain whether or not the relatives had the alternative type of disease. I now think there is no doubt that many instances occur within families of definite Crohn's disease affecting the small bowel and definite colitis confined to the colon and with no features of Crohn's disease.

Table III shows the data from the Colon Clinic of the Liverpool Royal

Table III

Liverpool colon clinic data

\begin{tabular}{|c|c|c|}
\hline & Ulcerative Colitis & Crohn's Disease \\
\hline $\begin{array}{c}\text { Propositi: } \\
\text { with ankylosing spondylitis }\end{array}$ & 103 & 39 \\
\hline First degree relatives: with ulcerative & 2 & 2 \\
with Crohn's disease colitis & 4 & 4 \\
with ankylosing spondylitis & 3 & 7 \\
\hline
\end{tabular}

Infirmary in which we investigated the patients in some detail and actually examined the relatives. We found very much the same as was found in Chicago. Amongst the Ulcerative Colitis patients there were seven who had Inflammatory Bowel Disease in their relatives, that is seven per cent, whilst in the Crohn's patients, 11 out of 39 had affected relatives ( 26 per cent). Again, note this higher incidence of positive family history amongst the Crohn's disease patients. Again there was the mixture of Ulcerative Colitis and Crohn's disease in the relatives and you will note that amongst the relatives we also found three people with ankylosing spondylitis but without evidence of Inflammatory Bowel Disease.

The data in Table IV were given at the 6th World Congress of Gastro-

Table IV

Data on Cleveland Clinic patients with onset of inflammatory bowel disease before the age of 21 years (Farmer 1978)

\begin{tabular}{|c|c|c|c|}
\hline Inflammatory bowel disease & Number of patients & \multicolumn{2}{|c|}{ Positive family history } \\
\cline { 2 - 4 } & & Number & Percentage \\
\hline Ulcerative Colitis & 315 & 93 & 29 \\
\hline Crohn's disease & 494 & 187 & 38 \\
\hline
\end{tabular}

enterology in Madrid in June 1978 by Richard Farmer from the Cleveland Clinic and they relate only to patients with an onset of the disease before the age of 21 . Out of the 315 Ulcerative Colitis patients, they found that no less than 29 per cent 
had a positive family history of Inflammatory Bowel Disease. In Crohn's disease it was even higher at 38 per cent with a positive family history. This high incidence of positive family history is very much what one finds in early-onset cases of diseases in which the genetic basis involves a number of different genes, in other words a polygenic basis. For instance, patients in whom duodenal ulcer develops under the age of 15 have a very high incidence of duodenal ulcer in the mothers and fathers, very often in both sides of the family $\left(\right.$ Cowan $\left.{ }^{5}\right)$. Similarly these young-onset Inflammatory Bowel Disease patients at the Cleveland Clinic have obviously got a very high familial component.

\section{Ankylosing spondylitis}

There have been many reports of colitics affected by ankylosing spondylitis, a much higher proportion than one would expect to find in a random sample of the population. Of the 142 patients investigated at the Liverpool Royal Infirmary Colon Clinic there were only four with ankylosing spondylitis, two of the Crohn's and two of the Ulcerative Colitis patients (see Table III). Amongst the first degree relatives there are three who had ankylosing spondylitis but no evidence of Inflammatory Bowel Disease. They have had barium enemas and sigmoidoscopies and we think that these relatives have ankylosing spondylitis without Inflammatory Bowel Disease. We have therefore got this curious relationship of a disease occurring with both Crohn's disease and Ulcerative Colitis but which can develop years before the bowel disease and is therefore not a complication. They occur in association with each other and this is another problem which has to be sorted out from the genetic point of view.

\section{HLA types}

Polygenic inheritance means many genes, very often genes on different chromosomes. Rapid advances are being made in the mapping of the human chromosomes and the chromosome that we are particularly interested in in gastroenterology is chromosome No 6 because on it are the HLA genes, located near the centromere. There are four HLA loci and quite a lot of gastro-intestinal and rheumatic diseases are associated with an abnormal distribution of the HLA types. We in Liverpool, and in other places, have investigated the HLA types in Inflammatory Bowel Disease and not found any particular abnormality in their distribution and I feel confident that the HLA types are not concerned in the aetiology of either Ulcerative Colitis or Crohn's disease. We found among 70 patients that nine (12.9 per cent) had HLA -B27, the HLA type which is found in 90 per cent of people with ankylosing spondylitis. In Liverpool about 7.5 per cent of the general population is positive for HLA-B27 and the number in the Inflammatory Bowel Disease patients is not significantly different from that, especially as one or two cases were included because they had ankylosing spondylitis. It is interesting that amongst the nine HLA-B27 patients four were males with ankylosing spondylitis (Table V). Amongst the five patients. who had HLA-B27 but did not have ankylosing spondylitis, three were females and therefore rather unlikely to develop the condition. So, four out of 
Table V

Seventy patients tested $\rightarrow$ HLA-B27 positive

\begin{tabular}{|c|c|c|}
\hline Inflammatory bowel disease & With ankylosing spondylitis & With normal sacro-iliacs \\
\hline Ulcerative colitis -6 & 2 males & $\begin{array}{c}1 \text { male } \\
3 \text { females }\end{array}$ \\
\hline Crohn's disease -3 & 2 males & 1 male \\
\hline
\end{tabular}

Note: Four of the six male HLA - B27 patients had ankylosing spondylitis.

the six male HLA-B 27 patients already had ankylosing spondylitis at the time of testing.

The number of HLA--B27 people in the population who develop ankylosing spondylitis is probably about 5 per cent. In contrast in this series of six, Inflammatory Bowel Disease patients of HLA-B27, 66 per cent have already developed ankylosing spondylitis. This indicates that Inflammatory Bowel Disease is a very potent initiating or potentiating factor in the development of ankylosing spondylitis and thus seems to contradict the statement I made earlier that ankylosing spondylitis is not a complication of Inflammatory Bowel Disease, but is in fact merely an accompanying disease. These data show that Inflammatory Bowel Disease is a potent factor in causing people who have HLA-B27 to develop ankylosing spondylitis. By HLA typing all our colitis and Crohn's patients we are now able to forecast the few of them who have a 66 per cent likelihood of developing ankylosing spondylitis.

\section{Genetic explanation}

Some years ago I put forward the theory that the explanation of these data is that these three diseases have certain genes in common in their genotypes $\left(\mathrm{McC}\right.$ Connel1 $\left.{ }^{\mathrm{B}}\right)$. In other words, there are over-lapping genotypes. For example, if there were ten genetic loci involved in determining whether or not you develop each of these three diseases, three or four of the genes may be common to the three genotypes. Thus somebody could have ankylosing spondylitis and Ulcerative Colitis by chance. Another patient could have both Ulcerative Colitis and Crohn's disease but then you run up against what is almost a rule that we all follow. We never diagnose both diseases in the same patient. If we think a patient has got Ulcerative Colitis but the biopsy in one part comes up with granulomata we say it is Crohn's disease. I no longer believe this theory of over-lapping genotypes because of my clinical opinion that Ulcerative Colitis and Crohn's disease are in fact variants of the same disease. In my own practice several patients who ten years ago had Ulcerative Colitis, fulfilling all the criteria for its diagnosis, have now got Crohn's disease. In them the clinical picture has changed.

I think now the much more likely explanation of Crohn's disease and Ulcerative Colitis occurring in the same family is that they have the same genotype. There may be ten or fifteen genes which make people liable to develop Inflammatory Bowel Disease. If a person has only a fow of these genes $\mathbf{I}$ think they are more liable to develop Ulcerative Colitis. But if they have a lot more of these 
genes, a more complete genotype, then the clinical and pathological picture that develops is more likely to be Crohn's disease. This would be an explanation of why the relatives of people with Crohn's disease are much more likely to have Inflammatory Bowel Disease than relatives of people of Ulcerative Colitis. If you have a patient with a lot of these genes the relatives will also have a good proportion of them. I think that in our present state of knowledge this is the most likely explanation of the familial pattern.

\section{Environment and heredity}

I do not want to rule out the possibility that genes are not involved at all, but that there is a common environmental influence. When we investigated my patients a year or two ago for familial pattern, we also studied their environment and we discovered a number of very curious things (Lewkonia and McConnell ${ }^{7}$ ). For instance, there was a young woman attending the olinic with Crohn's disease whose mother developed a very fulminating Ulcerative Colitis and died quite rapidly. Then we discovered that the man next door also had Crohn's disease. We also had a man who attended the clinic for the first time with Ulcerative Colitis and told us that he already knew two people coming to the clinic, one of them a work-mate and the other a nephew by marriage. We know of two other patients who live quite near to each other.

There is a town near Liverpool called Runcorn and a remarkable number of my patients with Crohn's disease but not with Ulcerative Colitis come from Runcorn. This may be chance but might be explained by Crohn's disease and Ulcerative Colitis being caused by two different environmental factors. However, I think the explanation most able to explain all the data is that Inflammatory Bowel Disease is due to an environmental factor which does not strike the whole population equally and that the people who are most likely to develop it are those with a certain genotype. If they have a full genotype they are more likely to develop Crohn's disease and if only partial they are more likely to develop Ulcerative Colitis.

\section{REFERENCES}

1. CROHN, B B (1934). The broadening conception of regional ileitis. American Journal of Digestive Diseases 1, 97/99.

2. Almy, T P AND Sherlock J A (1963). Genetic Aspects of Uilcerative Colitis and Regional Enteritis. Gastroenterology 51, 757-760.

3. Kirsner, J B AND SPENCER J A (1963). Familial occurrences of ulcerative colitis, regional enteritis and ileocolitis. Annals of Internal Medicine 59, 133-144.

4. KIRSNER J B (1973). Genetic aspect of inffammatory bowel disease. Clinics in Gastroenterology 2, 557-575.

5. Cowan, W K (1973). Genetics of duodenal and gastric ulcer. Clinics in Gastroenterology 2, 539-546.

6. MOCONNELL R B (1972). Genetics of Crohn's disease. Clinics in Gastroenterology 1, 321-334.

7. LeWKonia, $\mathbf{R}$ M AND MoConNell, $R$ B (1973). Familial inflammatory bowel diseaseheredity or environment? Gut 17, 235-243. 